$$
\text { UC-426 }
$$

\title{
RATIONAL CHOICES FOR THE WAVELENGTHS OF A TWO COLOR INTERFEROMETER
}

BY

F.C. JOBES

JULY 1995

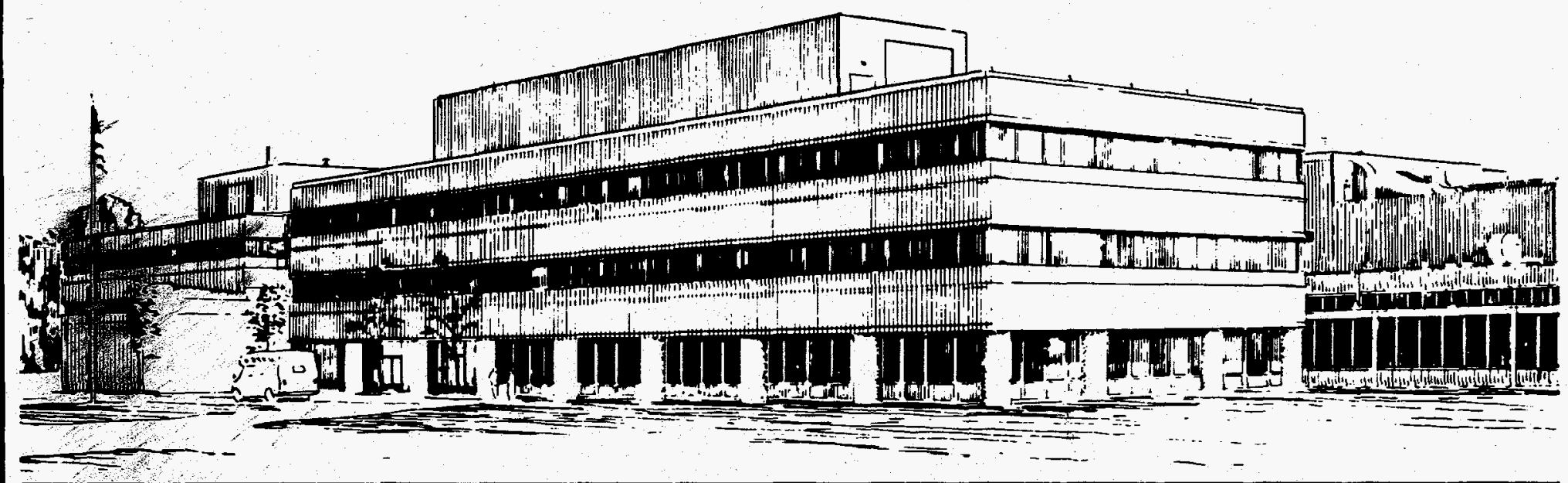




\section{NOTICE}

This report was prepared as an account of work sponsored by an agency of the United States Government. Neither the United States Government nor any agency thereof, nor any of their employees, makes any warranty, express or implied, or assumes any legal liability or responsibility for the accuracy, completeness, or usefulness of any information, apparatus, product, or process disclosed, or represents that its use would not infringe privately owned rights. Reference herein to any specific commercial produce, process, or service by trade name, trademark, manufacturer, or otherwise, does not necessarily constitute or imply its endorsement, recommendation, or favoring by the United States Government or any agency thereof. The views and opinions of authors expressed herein do not necessarily state or reflect those of the United States Government or any agency thereof.

\section{NOTICE}

This report has been reproduced from the best available copy.

Available in paper copy and microfiche.

Number of pages in this report: 11

DOE and DOE contractors can obtain copies of this report from:

Office of Scientific and Technical Information

P.O. Box 62

Oak Ridge, TN 37831 ;

(615) 576-8401.

This report is publicly available from the:

National Technical Information Service

Department of Commerce

5285 Port Royal Road

Springfield, Virginia 22161

(703) $487-4650$ 


\section{DISCLAIMER}

Portions of this document may be illegible in electronic image products. Images are produced from the best available original document. 


\title{
Rational Choices for the Wavelengths of a Two Color Interferometer.
}

\author{
F. C. Jobes \\ Princeton Plasma Physics Laboratory, \\ P.O. Box 451, \\ Princeton, NJ 08543-0451
}

\begin{abstract}
If in a two color interferometer for plasma density measurements, the two wavelengths are chosen to have a ratio that is a rational number, and if the signals from each of the wavelengths are multiplied in frequency by the appropriate
\end{abstract}

\section{DISCLAIMER}

Portions of this document may be illegible in electronic image products. Images are produced from the best available original document. 
and selecting the desired Fourier component. The Fourier components have an integer relationship to the fundamental (frequency and phase); hence the need for a rational number.

On the face of it, the rational number $1: 1$ is worthless for a standard"interferometer, because the two signals cancel; in this case, one would use Faraday rotation ${ }^{2}$, and the two "colors" are the right and left hand polarized components of a linearly polarized laser source. In order for this to work at all, one needs to have and know a magnetic field along the line of sight. This is often the case in magnetic confinement plasma research, especially for sightlines along the confining field. The disadvantage of this technique is that the effect is small: the phase shift is reduced by the ratio $\omega_{c e} / \omega_{\text {laser }}\left(-10^{-3}\right)$ compared to the phase shift of a standard interferometer. ( $\omega_{\text {ce }}$ is the electron cyclotron frequency.)

The rational number 2:1 has not been used much in plasma devices $3.4,5$; however, it is a most sensible choice. In such a device, the plasma is probed by both a laser beam and its second harmonic. After passing through the plasma the fundamental laser beam is frequency doubled a second time; the interference is between the two frequency doubled components. In a plasma, the phase shift is proportional to wavelength, and the harmonic has half the phase shift of the fundamental. After doubling, the formerly fundamental phase shift is twice as big, and is compared to a half; the net phase shift is $3 / 2$ the phase shift one would get with the fundamental alone. The motion of optical components, on the other hand, is proportional to $1 / \lambda$, and the fundamental has half the phase shift of the harmonic; after doubling, they are exactly equal, and cancel completely. (Because there is a difference of index of refraction between the fundamental and the harmonic, there is a systematic window phase shift.) Frequency doubling works very well for YAG lasers at $1064 \mathrm{~nm}$, and suitable components are available off the shelf. This technique was originally developed for optical metrology $6,7,8$.

\section{The Rational Interferometer}

The third choice, a non-harmonic rational number such as 14:13 might not be realized exactly; however, with some lasers, particularly $\mathrm{CO}_{2}$ lasers, one can at least come close. It is good sense to do so. Consider a two color Michelson interferometer, in which both colors go in both legs, as in Fig. 1. Suppose also, that in the reference leg, there is a Bragg cell which frequency shifts both colors by some frequency (near 40 $\mathrm{MHz}$ ) before remixing with the measurement beam, and, finally, that the two colors are separated and detected independently. In the detectors, there are RF signals with phase shifts (now with respect to the Bragg cell 
driver frequency) appropriate to each color.

[As drawn, Fig. 1 shows the reference beam passing through the Bragg cell twice; this would result in a double frequency shift. Also, because Bragg cells deviate the frequency shifted beams by an amount proportional to $\lambda$, the box marked "Bragg Cell" would have to include either a dispersive wedge or a grating to provide compensation, or else there would have to be two retro-reflectors.]

Consider, further, that one wavelength, $\lambda_{1}$, is chosen for reasons of intensity, ease of use, etc., and that the second wavelength is: $\lambda_{2}=\Lambda_{2}+$ $\varepsilon$, where $\Lambda_{2}=(I / J) \lambda_{1}, I$ and $J$ are integers, and $\varepsilon$ (hopefully) is small. Suppose that in the detector electronics the RF signal for $\lambda_{2}$ is frequency multiplied by I and the $\lambda_{1}$ signal by $J$. Then, there exists in the electronics two high frequency signals which have a relative phase relationship in which the motion component is small. These two high frequency signals can be heterodyned against one another to produce one signal with a phase shift which is only (or predominately) the plasma density.

The phase contribution from the two colors can be written:

$$
\begin{aligned}
& \phi_{1}=\mathrm{P} \lambda_{1}+\mathrm{L} / \lambda_{1}, \\
& \phi_{2}=\mathrm{P} \lambda_{2}+\mathrm{L} / \lambda_{2}
\end{aligned}
$$

with $P$ the plasma contribution, $L$ the unbalanced length contribution, and $\lambda_{2}=(\mathrm{I} / \mathrm{J}) \lambda_{1}+\varepsilon . P \lambda_{1}$ is the plasma phase shift one would get with an interferometer at $\lambda_{1}, L / \lambda_{1}$ is the phase shift error from unbalanced lengths in that interferometer. Thus:

$$
\begin{aligned}
\mathrm{P} \lambda_{1} & =\lambda_{1}\left(\frac{\lambda_{1} \phi_{1}-\lambda_{2} \phi_{2}}{\lambda_{1}^{2}-\lambda_{2}^{2}}\right)=\mathrm{J} \frac{\left(\mathrm{J} \phi_{1}-\mathrm{I} \phi_{2}-\mathrm{J} \eta \phi_{2}\right)}{\left(\mathrm{J}^{2}-\mathrm{I}^{2}-2 \mathrm{~J} \eta-(\mathrm{J} \eta)^{2}\right)} \\
& =\frac{\Delta \phi-\mathrm{J} \eta \phi_{2}}{2 \mathrm{n}-2 \eta-\mathrm{J} \eta^{2}}
\end{aligned}
$$

where,

$\Delta \phi \equiv J \phi_{1}-\mathrm{I} \phi_{2}, \mathrm{n} \equiv \mathrm{J}-\mathrm{I}$, and $\eta \equiv \varepsilon / \lambda_{1} . \Delta \phi$ is the parameter of interest in the rational interferometer. It is given by:

$$
\begin{aligned}
& \Delta \phi \equiv J \phi_{1}-\mathrm{I} \phi_{2}=\mathrm{P} \lambda_{1}\left(\frac{\mathrm{J}^{2}-\mathrm{I}^{2}}{\mathrm{~J}}+\mathrm{I} \eta\right)+\eta \frac{\mathrm{L}}{\lambda_{2}}\left(\frac{1}{\left(1+\frac{\mathrm{J}}{\mathrm{I}} \eta\right)}\right) \\
& \Delta \phi \approx \mathrm{P} \lambda_{1}\left(2 \mathrm{n}\left(1-\frac{\mathrm{n}}{2 \mathrm{~J}}\right)\right)+\eta \frac{\mathrm{L}}{\lambda_{2}} .
\end{aligned}
$$

In a rational interferometer, $\Delta \phi$ is generated before phase detection, in appropriate frequency multiplication circuits or crystals. This signal is mostly plasma signal, with a small contribution from mirror motion. For instance, $\mathrm{P} \lambda_{1} \sim 1 \rightarrow 10$ fringe for a typical plasma + interferometer situation, (often $\sim 1$ fringe for a $\mathrm{CO}_{2}$ laser setup) and $\mathrm{L} / \lambda_{2} \sim 100$ fringe for $1 \mathrm{~mm}$ motion. $\eta$ can be $<10^{-4}(\varepsilon<1 \mathrm{~nm})$, so that the motional noise is 
$<0.01$ fringe.

On the other hand, in a standard two color

interferometer $9,10,11,12,13$, one measures the phases of the two signals independently, and determines the motional and plasma contributions by appropriate sums of the two signals. In both channels, the phase signal is completely dominated by the motion of mirrors and other optical components For a $10.6 \mu \mathrm{m}$ line, the motional noise would be hundreds of fringes; a line density of $2 \times 10^{20} \mathrm{~m}^{-2}$ would produce only 1 fringe. This, of course, requires the difference between two large numbers, both of which need to be measured very carefully.

Table 1 shows a set of wavelength ${ }^{14}$ pairs possible in $\mathrm{CO}_{2}$ lasers, which have a wavelength ratio near some rational number, along with the transition names, rational numbers, $\varepsilon$ expressed as phase error (in fringes $/ \mathrm{cm}=\varepsilon L / \lambda_{1} \lambda_{2}, L=1 \mathrm{~cm}$ ), and a signal to noise figure. This $S / N$ figure is the ratio of the detected phase shift for a density which, in a standard two color interferometer, would give 1 fringe, to the motional phase shift given by one $\mathrm{cm}$ of mirror motion. (That is, the signal is $\sim 2$ $10^{20} \mathrm{~m}^{-2}$, and the total length change is $1 \mathrm{~cm}$.) $\mathrm{S} / \mathrm{N}$ would be $\sim 0.001$ in a standard two color interferometer. The final column, named tunability, is the fraction of the natural line width (Doppler broadening of room temperature $\mathrm{CO}_{2}, \delta \lambda / \lambda \sim 10^{-6}$ ) each line would have to be detuned in order that the wavelength ratio would be exactly a rational number. (If both lines are extracted from a single laser, and if the laser length < $10^{5} \lambda$, the lines will be in the identified rational relationship; then the motional noise $=0$, and $S / N=\infty$.)

Table 1: Selected $\mathrm{CO}_{2}$ Laser wavelengths.

\begin{tabular}{|l|l|l|l|l|l|l|}
\hline$\lambda 1: \lambda 2$ (microns) & $\begin{array}{l}\text { Transition 1 } \\
\text { (in } 00^{\circ} \rightarrow 10^{\circ} \text { band:) } \\
\text { Transition 2 } \\
\text { band }\end{array}$ & $\begin{array}{c}\text { J:I } \\
\text { botional }\end{array}$ & $\begin{array}{l}\text { S/N } \\
\text { Noise in } \\
\text { fringes } / \\
\text { cm }\end{array}$ & $\begin{array}{l}\text { Tun- } \\
\text { ability }\end{array}$ \\
\hline $10.44059: 9.69483$ & $\mathrm{P}(4): \quad \mathrm{P}(36) 00^{\circ} 1 \rightarrow 02^{\circ} 0$ & $14: 13$ & $9.310^{-4}$ & 2078 & 0.0 \\
\hline $10.57105: 9.20073$ & $\mathrm{P}(18): \mathrm{R}(34) 00^{\circ} 1 \rightarrow 02^{\circ} 0$ & $54: 47$ & $5.210^{-2}$ & 251 & 0.5 \\
\hline $10.61136: 9.30539$ & $\mathrm{P}(22): \mathrm{R}(14) 00^{\circ} 1 \rightarrow 02^{\circ} 0$ & $65: 57$ & $6.710^{-2}$ & 224 & 0.5 \\
\hline $10.51312: 10.31843$ & $\mathrm{P}(12): \mathrm{R}(10) 00^{\circ} 1 \rightarrow 10^{\circ} 0$ & $54: 53$ & $1.410^{-2}$ & 144 & 0.1 \\
\hline $10.69639: 10.17033$ & $\mathrm{P}(30): \mathrm{R}(32) 00^{\circ} 1 \rightarrow 10^{\circ} 0$ & $61: 58$ & $6.610^{-2}$ & 88 & 0.6 \\
\hline $10.71857: 10.22001$ & $\mathrm{P}(32): \mathrm{R}(24) 00^{\circ} 1 \rightarrow 10^{\circ} 0$ & $43: 41$ & $6.610^{-2}$ & 60 & 0.8 \\
\hline $10.65316: 9.51981$ & $\mathrm{P}(26): \mathrm{P}(16) 00^{\circ} 1 \rightarrow 02^{\circ} 0$ & $47: 42$ & $1.910^{-1}$ & 51 & 2.1 \\
\hline
\end{tabular}

Table 2: Selected $\mathrm{CO}_{2}$ line paired with $\mathrm{He}-\mathrm{Ne}$ line.

\begin{tabular}{|l|l|l|l|l|l|l|}
\hline 10.12535: 0.632816 & $\mathrm{P}(42) 00^{\circ} 1 \rightarrow 10^{\circ} 0:$ He-Ne & $16: 1$ & $2.810^{-2}$ & 37 & 14 \\
\hline
\end{tabular}

Table 1 is a very small sampling of possible wavelengths: $\lambda_{1}$ is 
restricted to the $00^{\circ} 1 \rightarrow 10^{\circ} 0 \mathrm{P}$ band, and only transitions near th center of the selected bands were looked for (P(n) or R(n), $4 \leq n \leq 40)$. The selected bands are: $00^{\circ} 1 \rightarrow 10^{\circ} 0 \mathrm{P}$ and $\mathrm{R}, 00^{\circ} 1 \rightarrow 02^{\circ} \mathrm{O} \mathrm{P}$ and $\mathrm{R}$. The table lists the transitions with the largest $S / N$. These transitions give a factor of about $10^{5}$ improvement over irrationally chosen lines.

[Table 2 shows a comparison between the common He-Ne line at $633 \mathrm{~nm}$, and a weak $\mathrm{CO}_{2}$ line with a wavelength 16 times longer. There are also $\mathrm{CO}_{2}$ lines in the vicinity of $10 \mu \mathrm{m}$ which are near the rational number $\mathrm{J} / 3$, for $43 \leq \mathrm{J} \leq 52$.]

All the $\mathrm{CO}_{2}$ transition pairs in Table 1 have horrendous looking integers, except for the first pair, with the best $S / N$, which has 14 and 13. Unfortunately both lines in this pair are far from the center of their bands, and consequently likely to be very weak. The lines of the pair in the third row are near the band center, but the integers are 65 and 57. However, the situation is not quite as bad as it looks, because these integers can be obtained by addition and subtraction (via mixing) as well as multiplication, and the phase differencing can be done at any point in the process. Thus, $65 \phi_{1}-57 \phi_{2}$ can be achieved by $65 \delta \phi+8 \phi_{2}$ or by $57 \delta \phi$ $+8 \phi_{1}$, where $|\delta \phi|=\left|\phi_{1} \pm \phi_{2}\right|$. The integers 65 and 57 can be achieved by many routes.

For instance suppose, in this case, and for the interferometer of Fig. 1, that the signals are at $80 \mathrm{MHz}$, and that the signal for $\lambda_{2}$ is heterodyned to both $85 \mathrm{MHz}$ and $40 \mathrm{MHz}$. If these signal at $85 \mathrm{MHz}$ is heterodyned against the $\lambda_{1}$ signal at $80 \mathrm{MHz}$, and the difference signal at $5 \mathrm{MHz}$ multiplied by 65 , we would end at $325 \mathrm{MHz}$ with a phase shift $65^{*}\left(\phi_{1}-\phi_{2}\right)$. If the $40 \mathrm{MHz} \lambda_{2}$ signal is multiplied by 8 to $320 \mathrm{MHz}$, and that heterodyned with the $325 \mathrm{MHz}$ signal, we would end up with a signal at $5 \mathrm{MHz}$ with the desired phase relation $\left(65 \phi_{1}-57 \phi_{2}\right)$ and we would have used a fairly small part count; 1 tripler, 1 quintupler, 2 quadruplers, 1 doubler and 4 heterodyne circuits.

The line density resolution that can be achieved is:

$$
\delta\left(P \lambda_{1}\right)_{\mathrm{r}}=\left(\frac{\mathrm{J}}{\mathrm{J}^{2}-\mathrm{I}^{2}}\right) \Delta \phi \text {, where } \Delta \phi \text { is the resolution of the phase }
$$

detector, and the line density is expressed in terms of fringes of the longer wavelength of a two color interferometer, and the subscript ' $r$ ' refers to the technique using rational numbers. By comparison, the density resolution of a standard two color interferometer (subscript ' $2 c$ '), would be:

$$
\delta\left(\mathrm{P} \lambda_{1}\right)_{2 c}=\left(\frac{\lambda_{1}}{\lambda_{1}^{2}-\lambda_{2}^{2}}\right)\left(\lambda_{1} \delta \phi_{1}-\lambda_{2} \delta \phi_{2}\right)=\delta \phi\left(\frac{\lambda_{1}}{\lambda_{1}^{2}-\lambda_{2}^{2}}\right) \sqrt{\lambda_{1}^{2}+\lambda_{2}^{2}}
$$

The second expression on the right considers the two phase detectors to have the same resolution; they are added in quadrature. If $\Delta \phi=\delta \phi$, and 
$\mathrm{J} / \mathrm{I}$ is a good approximation to $\lambda_{1} / \lambda_{2}$, then the ratio of the line density resolutions is:

$$
\frac{\delta\left(\mathrm{P} \lambda_{1}\right)_{\mathrm{r}}}{\delta\left(\mathrm{P} \lambda_{1}\right)_{2 \mathrm{c}}}=\frac{1}{\mathrm{~J} \sqrt{1+\frac{\lambda_{2}^{2}}{\lambda_{1}^{2}}}}=\frac{1}{\sqrt{\mathrm{J}^{2}+\mathrm{I}^{2}}}
$$

This ratio is $1 / 86$ for the case $\mathrm{J}=65, \mathrm{I}=57$; for $14: 13$ it is $1 / 19$. For situations in which $\lambda_{2} \sim \lambda_{1}, \mathrm{I} \sim \mathrm{J}$, the ratio is $\sim 1 / \mathrm{J} \sqrt{ } 2$; the factor of $\sim \sqrt{2}$ coming from having 1 phase detector, instead of 2 in quadrature, and the factor of $J$ coming from multiplying the phase (one of them, anyway) by $J$, but presuming the phase detector has the same resolution as in the irrational case.

\section{Rationalizing the Irrational}

If the choice of laser lines cannot be made on the basis of a rational number, then the problem can be inverted: what rational number is close enough to the actual ratio to make the motional noise negligible. There is always such a rational number; the practical problem is to find usable integers (just a few stages of doublers, triplers, mixers, etc.) which would nevertheless reduce the motional error to a small correction. At worst, one would have a small error which would have to be determined from a phase measurement of the $\lambda_{2}$ signal. Then, one would have one measurement which is predominantly the plasma density, and another measurement which is predominantly the correction. As an added benefit, this second phase detector could be quite wide band, to look at high frequency effects, which don't need any correction for motional noise.

If one already has a two color interferometer with Bragg cells incorporated in it, then one could rationalize it, or at least make it less irrational, by merely adding new electronics circuitry, which look at the RF signals in parallel with the existing circuitry, and which performs the necessary multiplications and mixing. This can be done, even if the wavelengths are not adjusted to be more suitable to the rational interferometer.

\section{Advantages}

The advantages of using this rational number technique for twocolor interferometers are that the effects of motion can be nearly canceled out, and thereby reduced to a small correction to the measured phase; the smallest resolvable line density, for a given ability to resolve phase, is smaller (by a factor of $\sim \sqrt{\mathrm{J}^{2}+\mathrm{I}^{2}}$ ); the dynamic range of the phase detector is much smaller, and devoted almost completely to the desired 
plasma phase measurement; there is no need for a massive support structure; and, because the interferometer is insensitive to vibration, optical components (such as retro-reflectors) can be mounted to the vacuum vessel.

\section{Acknowledgments}

The author would like to thank Drs. D. W. Johnson, H. K. Park, N. L. Bretz, D. K. Mansfield and K. M. Young for encouragement and many heplful discussions. This work was supported by the U.S. Department of Energy, Contract No. DE-AC02-76-CH0-3073.

\section{References}

1. The Random House Dictionary of the English Language, College Edition, Random House, New York (1968).

2. F. C. Jobes, Rev. Sci. Instrum. 66, 386 (1995). F.C. Jobes and D. K. Mansfield, Rev. Sci. Instrum. 63, 5156 (1992).

3. F.A. Hopf, A. Tomita, and G. Al-Jumaily, Opt. Lett. 5, 386 (1980).

4. Eh.P. Kruglyakov, in "Diagnostics for Contemporary Fusion Experiments," P.E. Stott, D.K. Akulina, G. Gorini and E. Sindoni (Eds.) (SIF, Bologna, 1991), pp 99-101.

5. P.A. Bagryanskij, V.P. Drachev, Yu.I. Krasnikov, Proc. National Conf. on High-Temperature Plasma Diagnostics (USSR), Minsk, 1990.

6. G. V. Ostrovskaya, Kh. P. Alum. and Yu. V. Koval'chuk. "Dispersive Interferometer." Russian Patent No. 854,942.

7. F. A. Hopf and A. Tomito, Opt. Lett. 5, 39 (1980).

8. H. Matsumoto, Rev. Sci. Instrum. 65, 2894 (1994).

9. E. W. Newman, C. J. Buchenauer, and H. W. Hoida, Rev. Sci. Instrum. 57, 1992 (1986).

10. T. Lehecka, W. A. Peebles, N. C. Luhmann, Jr., and T. N. Carlstrom, Rev. Sci. Instrum. 59, 1580 (1988).

11. J. H. Irby, E. S. Marmar, E. Sevillano, and S. M. Wolfe. Rev. Sci. Instrum. 59, 1568 (1988).

12. E. Sevillano, J. H. Irby, B. Lipschultz, E. S. Marmar, and R. S. Post. Rev. Sci. Instrum. 59, 1591 (1988).

13. P. Innocente, S. Martini, A. Schio, and Ch. Ferrer Roca, Rev. Sci. Instrum. 61, 2885 (1990).

14. Wavelengths, wavenumbers and transition bands from: M. J. Weber, ed., CRC Handbook of Laser Science and Technology, Vol II Gas Lasers, CRC Press, Inc, Boca Raton (1986). The calculations shown in Table 1 used the 9 digit wavenumbers rather than the 6 digit wavelengths. 


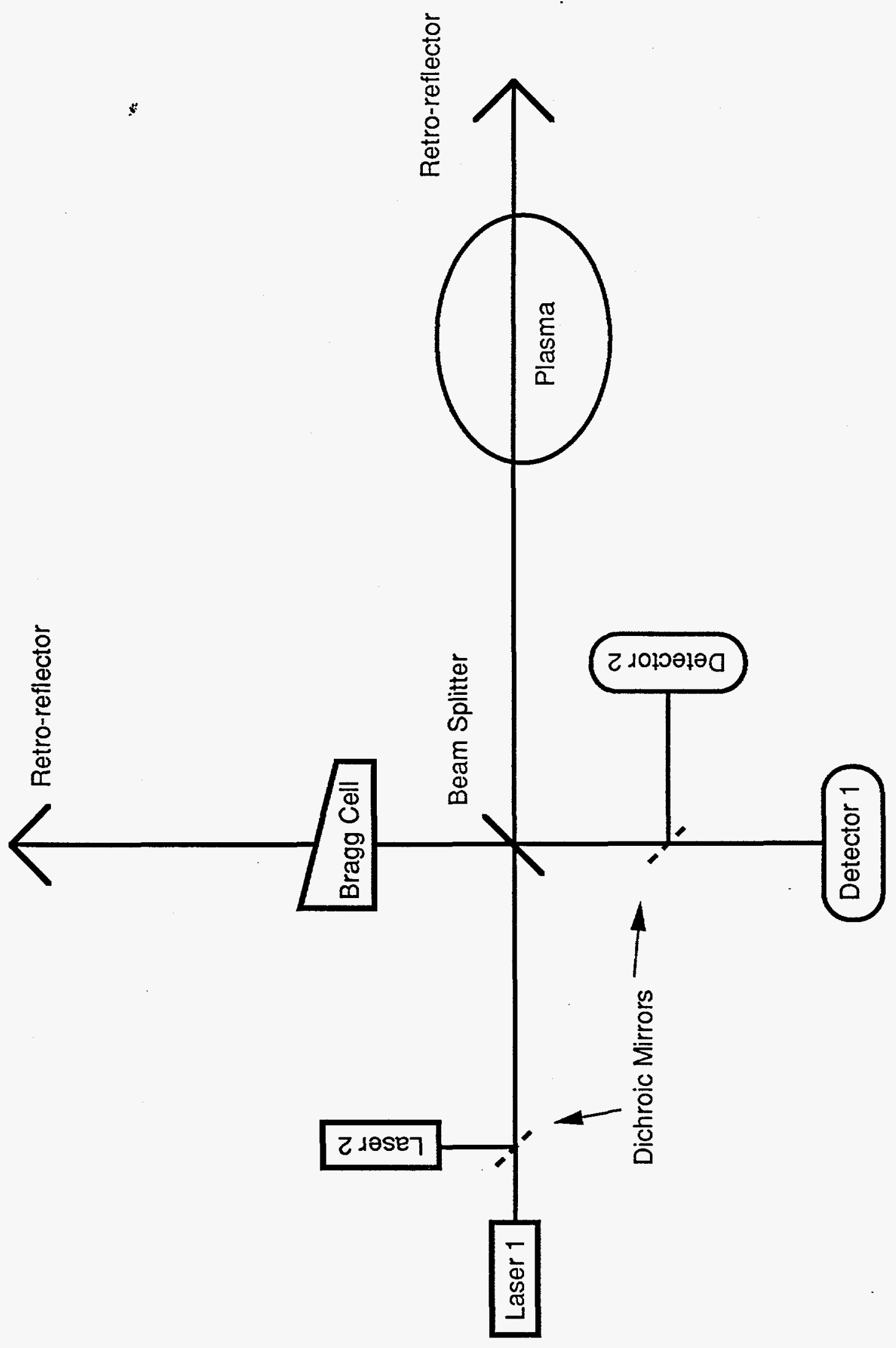


Dr. F. Paoloni, Univ. of Wollongong, AUSTRALIA

Prot. R.C. Cross, Univ. of Sydney, AUSTRALIA

Plasma Research Lab., Australian Nat. Univ., AUSTRALIA

Prof. I.R. Jones, Flinders Univ, AUSTRALIA

Prof. F. Cap, inst. for Theoretical Physics, AUSTRIA

Prof. M. Heindler, Institut für Theoretische Physik, AUSTRIA

Prof. M. Goossens, Astronomisch Instituut, BELGIUM

Ecole Royale Militaire, Lab. de Phy. Plasmas, BELGIUM

Commission-European, DG. XII-Fusion Prog., BELGIUM

Prof. R. Boucique, Rijksuniversiteit Gent, BELGIUM

Dr. P.H. Sakanaka, Instituto Fisica, BRAZIL

Prof. Dr. I.C. Nascimento, Instituto Fisica, Szo Paulo, BRAZIL Instituto Nacional De Pesquisas Espaciais-INPE, BRAZIL Documents Office, Atomic Energy of Canada Ltd., CANADA

Ms. M. Morin, CCFMTokamak de Varennes, CANADA

Dr. M.P. Bachynski, MPB Technologies, Inc., CANADA

Dr. H.M. Skarsgard, Univ. of Saskatchewan, CANADA

Prof. J. Teichmann, Univ. of Montreal, CANADA

Prof. S.R. Sreenivasan, Univ. of Calgary, CANADA

Prof. R. Marchand, INRS-Energie et Materiaux, CANADA

Dr. R. Bolton, Centre canadien de fusion magnétique, CANADA

Dr. C.R. James, Univ. of Alberta, CANADA

Dr. P. Lukác, Komenského Universzita, CZECHO-SLOVAKIA

The Librarian, Culham Laboratory, ENGLAND

Library, R61, Rutherford Appleton Laboratory, ENGLAND

Mrs. S.A. Hutchinson, JET Library, ENGLAND

Dr. S.C. Sharma, Univ, of South Pacific, FIJI ISLANDS

P. Mähönen, Univ. of Helsinki, FINLAND

Prof. M.N. Bussac, Ecole Polytechnique, FRANCE

C. Mouttet, Lab. de Physique des Milieux lonisés, FRANCE

J. Radet, CEN/CADARACHE - Bat 506, FRANCE

Prof. E. Economou, Univ. of Crete, GREECE

Ms. C. Rinni, Univ. of loannina, GREECE

Preprint Library, Hungarian Academy of Sa., HUNGARY

Dr. B. DasGupta, Saha Inst. of Nuclear Physics, INDIA

Dr. P. Kaw, Inst. for Plasma Research, INDIA

Dr. P. Rosenau, Israel Inst of Technology, ISRAEL

Librarian, Intemational Center for Theo Physics, ITALY

Miss C. De Palo, Associazione EURATOM-ENEA, ITALY

Dr. G. Grosso, Istituto di Fisica del Plasma, ITALY

Prof. G. Rostangni, Istituto Gas lonizzati Del Cnr, ITALY
Dr. H. Yamato, Toshiba Res \& Devel Center, JAPAN

Prof. 1. Kawakami, Hiroshima Univ., JAPAN

Prof. K. Nishikawa, Hiroshima Univ., JAPAN

Librarian, Naka Fusion Research Establishment, JAERI, JAPAN

Director, Japan Atomic Energy Research Inst., JAPAN

Prof. S. Itoh, Kyushu Univ., JAPAN

Research Info. Ctr., National Instit. for Fusion Science, JAPAN

Prof. S. Tanaka, Kyoto Univ., JAPAN

Library, Kyoto Univ., JAPAN

Prof. N. Inoue, Univ. of Tokyo, JAPAN

Secretary, Plasma Section, Electrotectinical Lab., JAPAN

Dr. O. Mitarai, Kumamoto Inst. of Technology, JAPAN

Dr. G.S. Lee, Korea Basic Sci. Ctr., KOREA

J. Hyeon-Sook, Korea Atomic Energy Research Inst, KOREA

D.I. Choi, The Korea Adv. Inst. of Sai. \& Tech., KOREA

Leandro Melendez Lugo, Inst. Nact. de Inves. Nud, MEXICO

Prof. B.S. Liley, Univ. of Waikato, NEW ZEALAND

Inst of Physics, Chinese Acad Sci PEOPLE'S REP. OF CHINA

Library, Inst. of Plasma Physics, PEOPLE'S REP. OF CHINA

Tsinghua Univ. Library, PEOPLE'S REPUBLIC OF CHINA

Z. Li, S.W. Inst Physics, PEOPLE'S REPUBLIC OF CHINA

Prot. J.A.C. Cabral, Instituto Superior Tecnico, PORTUGAL

Prof. M.A. Hellberg, Univ. of Natal, S. AFRICA

Prof. D.E. Kim, Pohang Inst. of Sci. \& Tech., SO. KOREA

Prof. C.I.E.M.A.T, Fusion Division Library, SPAIN

Dr. L. Stenflo, Univ. of UMEA, SWEDEN

Library, Royal Inst. of Technology, SWEDEN

Prof. H. Wilhelmson, Chalmers Univ. of Tech., SWEDEN

Centre Phys. Des Plasmas, Ecole Polytech, SWITZERLAND

Bibliotheek, Inst. Voor Plasma-Fysica, THE NETHERLANDS

Asst. Prof. Dr. S. Cakir, Middle East Tech. Univ., TURKEY

Dr. V.A. Glukhikh, Sci. Res. Inst. Electrophys.I Apparatus, USSR

Dr. D.D. Ryutov, Siberian Branch of Academy of Sa., USSR

Dr. G.A. Eliseev, I.V. Kurchatov Inst., USSR

Librarian, The Ukr.SSR Academy of Sciences, USSR

Dr. L.M. Kovrizhnykh, Inst. of General Physics, USSR

Kernforschungsanlage GmbH, Zentralbibliothek, W. GERMANY

Bibliothek, Inst. Für Plasmaforschung, W. GERMANY

Prof. K. Schindier, Ruhr-Universitát Bochum, W. GERMANY

Dr. F. Wagner, (ASDEX), Max-Planck-Institut, W. GERMANY

Librarian, Max-Planck-Institut, W. GERMANY 